\title{
A.H. Verhoef
}

\section{POSTMODERNISM AND THE NEED FOR STORY AND PROMISE: HOW ROBERT JENSON'S THEOLOGY ADDRESSES SOME POSTMODERN CHALLENGES TO FAITH ${ }^{1}$}

\section{ABSTRACT}

Modernity's belief that we live in a narratable world (a world with a story) and its confidence in progress (a world with a promise), are terminated by postmodernism's insights. This is how the American Lutheran theologian Robert Jenson understands the impact of postmodernism. If this is true, it poses great challenges for the Christian faith to be communicated and accepted within this context. This article assesses how Jenson's theology attempts to address postmodernism's need for a new story and promise. It concludes that Jenson's theology, as a Trinitarian theology, forms a coherent answer to these challenges because it is a narrative and eschatological theology. This article indicates, amongst other things the importance of Jenson's understanding in his theology of the relation between God and time. The significance of Jenson's approach is that it, firstly, understands the church as a narratable world, with a visible promise, and that it, secondly, follows a characteristically postmodern methodology in addressing these challenges.

1 This article is a revised version of a paper that was delivered at the international conference on "Faith in Face of Secularism" at St. Augustine College in Johannesburg in August 2011.

Prof A.H. Verhoef, North-West University. E-mail: Anne.Verhoef@nwu. ac.za.

Acta Theologica

2012 32(1): 170-188

DOl: http://dx.doi.org/10.4314/actat.v32i1.9

ISSN 1015-8758

() UVIUFS

<http://www.uovs.ac.za/ActaTheologica> 


\section{INTRODUCTION}

It is a cliché to say we live in a postmodern world, and indeed "postmodern" has become one of the most used and abused words in "modern" discourse. Yet it is striking how difficult it is to define postmodernism. In a general sense it can be regarded as a rejection of cultural certainties on which life in the West has been structured in the past couple of centuries. Notions like progress, the Enlightenment project, structuralism and grand narratives have been called into question. We can say that while the Western world is now "post"-modern in the sense that modernity is dying around us, it is not "post"-modern in the sense that any new thing is yet replacing it. Rather, postmodernism reflects the pluralism and relativism of contemporary thought in many fields, also in the religious. For postmodernism the truth no longer exists, only truths, and it raises therefore some serious questions about the status of religion, metaphysics and God-talk. This is evident from postmodernism's rejection of metanarratives and its admission of "defeat in the face of humankind's great questions, including the question of God, declaring itself to be incompetent or indifferent" (Kasper 2009:295) about it. ${ }^{2}$ The story of postmodernism is ironically the story of no stories no master narrative exists to interpret this world or the self. ${ }^{3}$ Furthermore, postmodernism is highly critical of any metaphysical assumptions and it is therefore not surprising that many theologians ask the question if and how it is possible to have faith in a postmodern society. ${ }^{4}$

2 Postmodernism is characterized by its "acceptance of the plural and the rejection of grand narratives of progress and explanation" (Stanley 2008:23). Jenson's reaction to postmodernism is specifically against Nietzsche's nihilism - "an historical reality defined purely by negations" - and he says that most of those who talk of postmodernism are belated disciples of Friedrich Nietzsche (Jenson 2010: 31).

3 An ontological position widely held in late-modern Continental thought (see for example Derrida's work) is that the personal self is said to be constituted in and by language, to subsist only as the act of self-interpretation. If the self is "linguistic, constituted in self-interpretation, and if language's history is discontinuous, then so is the self's history; then the self is constituted only as an endless bricolage of succeeding self-interpretations. A human life can have no status as a whole; that is, there is no self" (Jenson 1997:121 fn 21).

4 Postmodernism is indeed something that impacts the whole society on a practical level and it is not only an academic term. Jenson (2010:32) says, for example, that postmodernism "is seen in the general culture", in daily life and not only in art, philosophy, politics or theology. Graham Ward describes the emerging postmodern culture as "a culture of seduction and flagrant, selfconsuming sexuality; a culture of increasing sophisticated drugs and drug use; a culture of virtual, video-taped realities" (Ward 1997:2). 
Since the late twentieth century theologians have been developing a postmodern theology and they have been especially engaged with the philosopher Nietzsche (Ford 1997:11). This is understandable if we consider that Nietzsche radically questioned the whole concept of truth. ${ }^{5}$ The Eastern orthodox theologian David Hart, for example, describes postmodernity - in line of Nietzsche's thought - as

an awareness that all metanarrative structures stand upon a shifting surface of dead and living metaphors, while all 'truths' are endlessly fluid (Hart 2003:7).

For postmodernity, the truth is something that is competed for, a matter of power, because truth is according to Nietzsche the lie socially agreed upon. In this context the "radical orthodoxy" reacted to postmodernism under the initiative of John Milbank. ${ }^{6}$ The radical orthodoxy's reaction to postmodernism is that Christianity cannot prove its case, but must and can offer a rhetoric of peace in contrast with the Nietzschean rhetoric of violence. ${ }^{7}$ To some extent the American Lutheran theologian Robert

5 Nietzsche claimed: "What, then, is truth? A mobile army of metaphors, metonyms, and anthropomorphisms - in short, a sum of human relations... which after long use seem firm, canonical, and obligatory to a people: truths are illusions about which one has forgotten that this is what they are; metaphors which are worn out..." (1954:46).

6 Milbank is an English philosophical theologian who taught at the University of Virginia and presented his case for Christianity in a postmodern world in his book Theology and Social Theory (1990). The Radical Orthodoxy movement was founded by Milbank and others and takes its name from the title of a collection of essays published by Routledge in 1999: Radical Orthodoxy, A New Theology, edited by John Milbank, Catherine Pickstock and Graham Ward. Although the principal founders of the movement are Anglicans, Radical Orthodoxy includes theologians from a number of church traditions.

7 Milbank's claim is that post-Nietzschean philosophers assert that truth is to be decided only as a struggle among competing powers. For them this is however just a story too, potentially one among others and therefore, in this framework Milbank offers a Christian counterstory. Christianity, he says, "declares that the world is ultimately not about power but about love" (Placher 2004:42). For Milbank, the world that God created is made for peace, not violence, and so violence is always a distortion of the true nature of things. "Thus the Nietzschean story of how things are is really a story of how things have become distorted. Christianity's story of love and peace is the truer story" (Placher 2004:42). Milbank offers then a rhetorical argument in its favour. David Hart follows the same strategy in his theology in his The Beauty of the Infinite (2003) but emphasized that the persuasion of the Christian story lies on an aesthetic level. 
Jenson ${ }^{8}$ shares this view and he argues that the founding thinkers of postmodern epistemic nihilism interpreted violence (as what always really happens in human discourse) as an ontological ultimate (Jenson 1999a:148). For Jenson, postmodernism is the phenomenon of modernity's self-destruction and according to him modernity's belief that we live in a narratable world and its confidence in progress are terminated by postmodernism's insights. His theology can be described as an attempt to address postmodernism's need for a "new story and promise". The significance of this article is that it will indicate how Jenson's theology as a Trinitarian theology provides a coherent answer to these challenges of postmodernism. Although some aspects of Jenson's theology may be criticized, this article concludes that Jenson's theology as a whole is indeed helpful for broadening one's perspective of how faith can be kept in a postmodern society. ${ }^{9}$

\section{A WORLD THAT LOST ITS STORY AND PROMISE}

In his article, "How the world lost its story" (2010), Jenson identifies story and promise as the most important challenges that postmodern theology must address. Jenson describes story as "realistic narrative" (as Hans Frei described it) - as the modern world's typical way of knowing human life. Realistic narrative is a "particular way of telling a sequence of events that is distinguished from other possible forms by two characteristics" (2010:32). The first characteristic is that the sequel of events is to be understood jointly to make a certain kind of sense - "a dramatic kind of sense" (Jenson 2010:32) in which events are unpredictable but as soon as they happen one realises that that is exactly what should have happened. The second characteristic of realistic narrative is that the "sequential dramatic coherence is of a sort that could 'really' happen" as if there is a world "out there" external to the text (Jenson 2010:32).

In following these characteristics of realistic narrative Jenson says that modern Westerners suppose that stories are the appropriate way for them to understand their human task and being. In the modern West we have "supposed that we somehow 'ought' to be able to make dramatic sense of our lives" (Jenson 2010:32) and we further supposed that some stories

8 For a description of Jenson's theological works and their importance, see my article "How is Robert Jenson telling the story?" (2008).

9 Jenson says "it is modernity's time of ending as such that constitutes the Western Church's postmodern mission field... so the Church must now live and conduct her mission in the precisely 'post'-modern world” (2010:32). 
may be fitted to the "real" world as if the world itself makes dramatic sense. Jenson explains:

modernity has supposed we inhabit what I will call a 'narratable world'. Modernity has supposed that the world 'out there' is such that stories can be true of it. And modernity has supposed that the reason narratives can be true to the world is that the world somehow 'has' its own story, antecedent to, and enabling of, the stories we tell about ourselves in it (Jenson 2010:33).

Western modernity came by this supposition, according to Jenson, through the secularization of Jewish and Christian practice of using the Bible as archetypical body of realistic narrative. Modernity has imitated this realistic narrative (with the difference that it left God behind), but postmodernity has lost this supposition in all of its aspects. ${ }^{10}$ According to Jenson the West has lost its faith in a narratable world because it rejected God as part of the Enlightenment but tried to keep faith in the story of the world: "Modernity was defined by the attempt to live in a universal story without a universal storyteller" (Jenson 2010:33). ${ }^{11}$ The consequence was however that the story of the world was lost in the end - if there is no universal storyteller then the universe can have no story line.

With the world that has lost its story, without a narratable world, realistic narrative became implausible as a means for people's self-understanding. Jenson says

Human consciousness is too obscure a mystery to itself for us to script our own lives. Modernity has added a new genre ... the absurdist drama that displays precisely an absence of dramatic coherence (Jenson 2010:34).

While this was first visible in literature and art, general culture has now caught up with postmodernism and many people do not and cannot any longer understand their lives as realistic narratives (Jenson 2010:34). The

10 Not only God's existence is now left out, but the whole notion of any narrative's existence. Jenson says that this is most vividly visible in literature, but also in visual art such as surrealism. While the "classical visual art of the modern West was once realistic and narrative", postmodern art is defined precisely by a "passion to avoid any such a portrayal" (Jenson 2010:33).

11 David Hart agrees here with Jenson when he says "the 'modern' indicates not a single comprehensive narrative, but a single metanarrative ambition: a desire to transcend the conditioned finitude and contingency of stories by discovering the meaning, limits, and motives of all stories, by way of a representation of the absolute, the universal, or the rational" (Hart 2003:6). In contrast, postmodernity is an awareness that no such narrative (or even ambition for it) is possible. 
world became a place where no stories can be true and where Christianity becomes part of a relativistic option next to other religions or yoga. To find meaning in one's life in this context becomes extremely difficult because one's life has no story and it cannot be connected to a broader story to give it meaning because that story also does not exist (or vice versa as Jenson explains it).

It is, however, not only the world's story that has been lost in postmodernism, but also its promise. The promise of modernity was (also as a secularization of Christian eschatology) its "notorious confidence in progress" and this was "constitutive for modernity's whole practice and self-understanding" (Jenson 2010:35). This faith in progress was destroyed by, among others, the two World Wars and now

modernity has no resource either for renewing it or for acquiring any sort of hope. The mere negation of faith in progress is sheer lack of hope; and hopelessness is the very definition of postmodernism (Jenson 2010:36).12

Jenson indicates a further problem: promise becomes impossible in a world without a story - "promises can be made only if reality ... has a plotted story" (Jenson 2010:36). This impossibility of promises is something we experience in our daily lives and the marital promise of faithfulness until death is perhaps the best example of our inability to keep promises. The problem is that if reality has no plotted story, there can be no faith in world of promise. People therefore not only live without hope for the world but also without hope for themselves and consequently do not value any promise they make - it becomes meaningless.

Jenson thus identifies story and promise as the main challenges for keeping faith in a postmodern world. Story entails that people no longer understand the world as narratable and that they have consequently lost their narrative sense of their lives. For these people no story (on individual or universal scale) is true and therefore, for them, to believe in the gospel as the story is very problematic. How should the church then communicate her story in this context? For Jenson the obvious answer is that the church herself must be a narratable world. He says that

12 There is a strong connection between postmodernism and nihilism throughout Jenson's work and he is in constant reaction to both. He says, for example: “... the threat of nihilism is the defining evil from which the church has to rescue the inhabitants of Western late modernity" (Jenson 2000b:5). 
if the Church does not find her hearers antecedently inhabiting a narratable world, then the Church must herself be that world (Jenson 2010:34).

Jenson makes specific proposals how this can be done and this will be explored in the discussion of his theology. Jenson also offers suggestions on how to overcome the second challenge, namely that the world no longer entertains any promises. As an answer to this problem Jenson suggests that the "Church must herself be a communal world in which promises are made and kept" (Jenson 2010:36). For Jenson this means, for example, that the church's assemblies must be unabashedly events of shared apocalyptic vision. How he thinks this should be done will be further discussed in this article.

\section{JENSON'S NARRATIVE THEOLOGY OF PROMISE}

In his article, "How the world lost its story" $(1993,2010),{ }^{13}$ Jenson makes some preliminary proposals of how the church can overcome the two main challenges of story and promise. In his Systematic Theology ${ }^{14}$ he continues this line of thought and gives an exposition of his initial proposals. However, although his theology is definitely a continuous reaction to postmodernity and its consequent nihilism (as Jenson understood it), his theology cannot simply be described as apologetic. ${ }^{15}$ It would be better to say that as part of his Trinitarian theology Jenson continues to focus on postmodernism and nihilism (which is apparent in his discussion of "post-Christians" and

13 This article was originally published in 1993 and was reprinted in a twentieth anniversary issue of the journal First Things in 2010. Jenson's book Story and Promise (as the two main characteristics of the Christian message for him) was published in 1973 and his Systematic Theology (that can be described as an expansion of his Story and Promise) in 1997 and 1999. Jenson was throughout his theological career deeply engaged with these two themes.

14 Systematic Theology, Volume 1: The Triune God (1997) and Systematic Theology, Volume 2: The Works of God (1999) - hereafter referred to as ST1 and ST2.

15 James Buckley (2000:21) says: "I take it that Jenson agrees with Barth that all apologetics must be 'supplementary, incidental, and implicit' to the dogmatic task... Jenson's theology might take the question to be a challenge of nihilism - the story that things amount to nothing, from which we can abstract a metaphysics focused on 'the awaited advent of nothingness." As mentioned before, in Jenson's thought there is a very strong link between nihilism and postmodernism. 
in several of his articles) ${ }^{16}$ and that his whole theology should thus be considered in this regard.

\subsection{TELLING, HEARING AND LIVING THE STORY}

For Jenson, in postmodernism the world is no longer a narratable world and it is therefore difficult for the church's hearers to believe or even understand the gospel story. He suggests that the church must herself be a "real, substantial, living world to which the gospel can be true" (Jenson 2010:34) in order for faith to be possible. So the church must herself be a narratable world and he says she must do it by recovering the classic liturgy of the church in all its "dramatic density, sensual actuality, and brutal realism" (Jenson 2010:35). It is important however that this would be a real world for her members and not just ritual illusion. The church's interior drama cannot be fiction because this drama's subject is the Creator-God who authors all reality. The liturgy must enact the specific story of this drama of the real presence of reality's God, or otherwise it will become sickly pretence. Jenson says that for this story to be real, to create this true narratable world within the church as reality, ${ }^{17}$ it is necessary to tell and hear God's story and not your or my story. In postmodernism this story must not be reduced to slogans (as modern Christianity, according to Jenson, often did) because it cannot be supposed that the hearers know they have a story or that they know the story's basic plot. ${ }^{18}$ Therefore it is important for Jenson to tell God's story as it is revealed through the name Father, Son and Holy Spirit - this is "a maximally compressed version of the one God's particular story" (Jenson 2010:35). ${ }^{19}$ Jenson's theology is

16 See for example his "Can we have a story?" (2000a); "Second Thoughts about Theologies of Hope" (2000c); "What is a Post-Christian?" (2002b) and "The strange New Word of the Gospel. Re-Evangelizing in the Postmodern World" (Braaten, CE \& Jenson, RW (eds.) 2002).

17 According to Jenson, Protestantism made the mistake in modernity to have "supposed that the real action is in the world and that what happens 'in church' can only be preparation to get back out into reality" (Jenson 2010:35). With a world that has lost her story the same approach cannot be followed in postmodernity and the church must herself be now the narratable reality.

18 For example: slogans like "redemption", "justification" and "liberation" only point to certain features of the Christian story and assume that the hearers know the rest of the story.

19 The specific names of the triune God as Father, Son and Holy Spirit are important for Jenson because these names "evoke God as the three actors of His one story and place the three in their actual narrative relation. Substitutes do not and cannot do this; 'Creator, Redeemer, and Sanctifier,' for example, neither narrates nor specifically names..." (Jenson 2010:35). 
thus an effort to tell this particular story of the triune God - a narrative Trinitarian theology.

The way in which Jenson tells the story of God always involves the specific story of the Trinitarian God - it is a history of God or God's history. Jenson adopts the rule of Karl Rahner in which the immanent Trinity is the economic Trinity and vice versa. This means that "God's external relations to the world provide the very arena in which God's internal relations take place" (Peters 1998:342). For Jenson it is thus God's story that identifies him and not some metaphysical abstraction from a De deo uno. According to Ted Peters (1998:343),

\begin{abstract}
Jenson's emphasis on the historical particularity of God's identity makes him a narrative theologian with an attitude. God's story takes on an ontological status - that is, the story of Jesus of Nazareth and the story of the Holy Spirit's presence in the church belong to the very being of God. God is not God without his story.
\end{abstract}

This is already apparent in the way Jenson begins his Systematic Theology when he discusses the identity of the Trinity as an event. ${ }^{20} \mathrm{He}$ states it clearly that God's identity cannot be found in a type of metaphysical transcendental being, but in concrete happenings, in his story of the resurrection of Jesus and of Israel's redemption out of Egypt. Jenson says there "is a story of God's life, in that it has a plot... the plot of the story the Bible tells" (2002a:41) and this story is always (from beginning to end) a Trinitarian story.

In Jenson's presentation of this Trinitarian story, the difference between the "immanent" Trinity and the "economic" Trinity almost vanishes ${ }^{21}$ so that there is no "analogical interval" between the two. ${ }^{22}$ This view of Jenson

20 This is also what Jenson does in an earlier book, The Triune Identity (1982), where he describes God as an event. He states "I must note that the intent to interpret God's reality as event is by no means original with me. In fact it is endemic in contemporary theology. Two major projects of twentieth-century theology have been largely devoted to carrying it out: that of Karl Barth's Church Dogmatics and that of 'process' theology" (Jenson 1982:179).

21 Pannenberg criticised Jenson on this point and said: "It is certainly true that the trinitarian God in the history of salvation is the same God as in His eternal life. But there is also a necessary distinction that maintains the priority of the eternal communion's explication in the history of salvation. Without that distinction, the reality of the one God tends to be dissolved into the process of the world" (Pannenberg 2000:50).

22 David Hart explains this "analogical interval" as the distinction between the immanent Trinity and the economic Trinity that has always been asserted by the Christian theology as "that what happens in the story of salvation is 
leads to a very specific understanding about the relationship between God and time. Jenson regards the definition of God's eternity as "timeless" as unbiblical and incompatible with the story of creation and redemption. ${ }^{23}$ God is not timeless, but God is identified by "specific temporal actions and is known within certain temporal communities by personal names and identifying descriptions thereby provided" (ST1:44). God is not timeless, but lively, active, an event. God's being should therefore according to Jenson be described as temporal infinity - a term that demonstrates God's self-liberation from temporal contingencies without extracting God from history. This description of God is for Jenson more biblical than the Greek concept of timelessness, and he says that the biblical God is not timeless but "takes time" (ST1:217). ${ }^{24}$ This temporal infinity or "timefullness" of God is not just something ascribed to God, it is part of the being of God, it is central to the relationships within the Trinity - it defines God. For Jenson there is even a clear connection between the poles of time and the mutual triune roles of Father, Son and Spirit. According to him the "Father is the 'whence' of God's life; the Spirit is the 'whither' of God's life; and... the Son is that life's specious present" (ST1:218-219). The way Jenson is thus telling the story of the triune God is one in which he focuses very much on the Trinity's relation to time and eternity. With his structuring of time within the Trinity, Jenson is trying, on the one hand, to avoid timelessness of God and, on the other hand, to maintain God's perichoresis. ${ }^{25}$

a perfect expression (or dramatic revelation) of how it would be even were there no creatures at all, but also that between his temporal expression and its eternal source there is a relation of grace. God is not affected by time, His eternal identity knows neither before nor after, and the incarnation of the Logos is in no sense necessary to or determinative of that identity" (Hart 2005:31).

23 Pannenberg (2000:49) says: "Jenson is surely right in contending that the God of the Bible is identified by temporal events, and indeed by a history of such events. He boldly integrates this insight with his Trinitarian theology by conceiving of the biblical narrative as 'the final truth of God's own reality' in the mutual relations of God the Father, His incarnate Son, and the eschatological accomplishment of their communion by the Spirit."

24 For Jenson God is God because he overcomes all boundaries. He explains: "Any eternity is some transcendence of temporal limits, but the biblical God's eternity is not the simple contradiction of time. What he transcends is not the having of beginnings and goals and reconciliations, but any personal limitation in having them... The true God is not eternal because he lacks time, but because he takes time" (ST1:217).

25 Perichoresis (peri - around; chorein - to contain) has to do with the space (chora) between (peri) the three persons of the Trinity - a mutual interpenetration within the Trinity. This space also includes their relation "in time" and it is in this regard that Jenson (2002a:41) says: "Now the point about God's life is that it is not stretched out on a time line external to him. There is no past 
Jenson's understanding of God and time is important, because traditionally the doctrines of Christ and of the Spirit's coming appeared only in the parts of the doctrines referring to our history, to what God does to and for us, but now Jenson structures these doctrines to appear as teaching about God himself, as narrative of the history with us with which and by which God identifies himself (ST1:60). God's story is thus not separate from us, but it includes us as the church, as the Body of Christ. The temporal location of the Son is thus important for Jenson and that has implications about Jesus' presence in the sacrament of the Eucharist and in the church. The suggestion from Jenson is that the risen Christ is simply identical with the church:

Christ is personally the second identity of God, and the totus Christus is Christ with the church; therefore the church is not the same way an opus ad extra as is the creation, even when it is perfected in God (ST2:167).

The incorporation into the risen Christ's own body is according to Jenson enacted in the church's celebration of the Eucharist and not only in the community of the church. Jenson thus agrees with the patristic interpretation of Eucharist as the commune (koinonein) with Christ, and the share in his body and his deity, as well as commune as the uniting with one another. ${ }^{26}$ Jenson uses the term communion-ecclesiology to describe this unique communion of the church and says that at the Eucharist we receive one another with Christ and Christ with one another; "we are precisely 'coembodiments' of Christ" (ST2:222). This understanding of communionecclesiology - as the church's communion in the Trinity - is possible because of Jenson's understanding of God's "timefullness".

The above concept of communion-ecclesiology has obvious relevance to Jenson's proposal that the church should be a narratable world. With the postmodern world that has lost its story, the gospel story is not so easy to believe as true any longer. Jenson's proposal is that the church should herself be a narratable world, always telling the story of the

to God's life, if by the past we mean what is back there at a different location on a time line than the present, so that we cannot get at it. And there is no future to God's life, if to have future is to be confronted as we are by advents that may break this unity with himself. But as God is the Father and the Spirit there are a Whence and a Whither in God; and as he is the Son there is a reconciliation of God's Whence and his Whither."

26 With the patristic father, John of Damascus, Jenson (1996:6) says "for because we all eat one loaf we become one body and one blood of Christ and members of one another; we may be said to be embodied with Christ (sussomoi tou christou)". 
Trinitarian God and enacting the story of the real presence of God in her liturgy. Jenson is telling this story in his narrative Trinitarian theology, but by emphasising that God is not a timeless God, but a God who can be identified by concrete events in history, he identifies the crucial place and role of the church as a true narratable world. It is thus important for Jenson to describe God as a God who himself has a story and that this story includes all time - it includes us and the world. Finally, it is in God's perichoresis that time is accommodated and in which the church finds her place as part of the Son's "specious present". The church receives thus a special place in this story about and of God - she is indeed the story of God self and she celebrates it as communion-ecclesiology in the liturgy and Eucharist. The coherence of Jenson's theology is thus clear if he emphasises that the church should herself be a narratable world and that her liturgy - especially in the Eucharist - should tell the story (and of the presence) of the Trinitarian God in this postmodern society.

\subsection{Seeing, telling and living the promise}

According to Jenson, in postmodernism it is not only the world's story that has been lost, but also its promise. Jenson's reaction to this is that the "Church must herself be a communal world in which promises are made and kept" (Jenson 2010:36). This makes sense in terms of his narrative Trinitarian theology because, firstly, promise only makes sense in a narratable world and Jenson gives this narrative in his theology and urges the church to be this narratable world, and secondly, when Jenson tells the story of the Trinitarian God it is a story that has not yet ended, but a story of which the end is well known. This story of God continues until the Spirit, as the future of us and God, will bring fulfilment. The climax of Jenson's theology is that the end will be theosis:

God and only God is the creature's future. God the Spirit is God's own future and so draws to and into the triune converse those for whom the Trinity makes room (ST2:26). ${ }^{27}$

The church is thus per definition a communal world of promise - she is, according to Jenson, already the totus Christus, but still exists in

27 Pannenberg says that it is at this point where Jenson's systematic unity of his theology is found: "unity is provided by the trinitarian perspective: from the beginning, the creation was intended for 'inclusion' in the triune community by virtue of union with Christ, the purpose being a 'perfected human community.' That is the promise of the gospel which is anticipated in the life of the Church and is finally achieved in the final advent of the Kingdom" (2000:49). 
anticipation and what she anticipates is the full inclusion in the triune communion.

The relationship between Trinity and time is again very important in the way Jenson explains the promise the church lives by, namely the eschaton. He says that because God is not timeless but has himself a history, we can say that what God creates (the universe) is a history - something with an intended end. Jenson argues that, since what God creates is a history, "the one conceivable end of history must be again a sublation, now into the only thing left to be taken into, God" (Jenson 2000c:341). His Trinitarian reaction against nihilism is clear when he says that an end of history, if not a sheer nothing, "can only be temporal history's sublation into the infinite history that Father, Son and Holy Spirit are between them" (Jenson 2000c:341). For Jenson, it is plain that

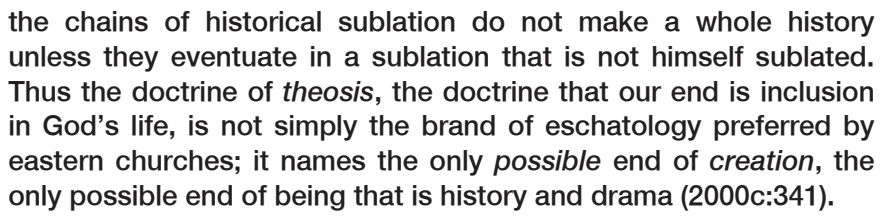

In a postmodern world the challenge for the church is thus to live with this promise in such a way that the truth of it will be evident to those who come into contact with the church. Jenson therefore emphasises that the church should be a community that makes and keeps promises, because she lives with the promise of fulfilment in God self - "the gospel is a promise" (ST2:309). This should be lived on a very practical level in the present, for example, by keeping marital promises, and by "mutual forgiveness and reparation" (Jenson 2002a:39) that should be visible to the world. Jenson (ST2:310) is herein careful not to strip the Bible's eschatology "of its specific temporal structure" and not to understand it only as a "drive toward future fulfilment" - something he accuses postmodern theology to be guilty of. ${ }^{28}$

Another important aspect regarding promise is that the church should, according to Jenson, be able to have a "concentrated vision" (Jenson 2002b:31) of the eschaton, and that "the church's assemblies must be unabashedly events of shared apocalyptic vision" (Jenson 2010:32). Jenson herein agrees with Karl Barth's view: "Christianity that is not entirely and altogether eschatology has entirely and altogether nothing to do with Christ" (Barth 1933:314). This vision of the eschaton cannot just be

28 Jenson specifically has Pannenberg's theology in mind here (see for example ST2:310 fn 4). 
a vision of "eternity"; ${ }^{29}$ it must be a vision of something clear, something with such content that it will give true hope for the church. Jenson (2010:36) therefore pleads that "preaching and teaching and hymns and prayers ... must no longer be shy about describing just what the gospel promises..." and that "the Church's assemblies must again become occasions of seeing". He does not shy away from describing this "beatific vision" and he devotes a whole chapter in his Systematic Theology to "The Promise". ${ }^{30}$ In answering his own question about what the gospel promises he says it is "inclusion in the triune community by virtue of union with Christ and just so in a perfected human community" (ST2:311). In this regard he refers to Basil the Great's description of our deification: "... the final result of the Spirit's work in us is 'endless joy in the presence of God, becoming like God, and... becoming God'” (ST2:311). Our apocalyptic vision should thus be one of "real Community, with its real Banquet in its real City amid its real splendour" (Jenson 2010:36). The image Jenson repeatedly uses to describe this vision of the end is that "God is a great fugue" (ST2:236) and that "the end is music" (ST2:369). ${ }^{31}$

\section{A POSTMODERN APPROACH IN A POSTMODERN SOCIETY}

Jenson's approach to find a true story and promise in a postmodern world which has lost its confidence in stories and promises might seem to be a very modern approach, especially because Jenson presents this story as another type of metanarrative. Jenson (2000a:17) says for example:

29 Jenson argues eternity (as unbounded futurity) cannot be a Christian's understanding of the eschaton, because that is an empty promise. He says that can only be experience as "the child's nightmare of eternity, in which at every moment there is always yet another moment, so that no journey can have a goal, no pain a termination, no joy a resting place, into which the meaning of every temporal act and sequence evaporates" (Jenson 1982:168-169). If eternity was just unbounded futurity, it "....would make little difference whether one were in heaven or hell, since a truly endless on and on and on... would merely in itself be intolerable" (Jenson 1999b:169).

30 The last part (VII) of his Systematic Theology Jenson calls "The Fulfillment" and under that heading he discusses: The Promise, The Last Judgement, The Great Transformation, The Saint and Telos.

31 Jenson (2002a:42) explains: "I followed Jonathan Edwards in proposing that the final word about God is that he is beautiful, and that as he is the biblical God, who is Whence and Whither, he is beautiful with the kind of beauty that music has. Indeed, I proposed that he is beautiful with the kind of beauty that a certain kind of music has. The last word about God, I said, is that he is a great fugue, of Father, Son, and Spirit. So the last word about us is this: the end is music." 
What is to be done within church and synagogue seems relatively plain. God's people must gather the courage to subordinate other narratives to their own, to proclaim and live within a metanarrative that is 'meta' in the superlative degree. If the story the Bible tells, running from creation to consummation and plotted by Exodus or Exodus-Resurrection, is true, it is not just our story but God's. If it is God's story, it is universal. And if it is the triune God's story, it cannot be oppressive.

As to the postmodern critique to such attempts he says

we can note the postmodernist critique of metanarratives, and then offer a narrative that, because it is about God and us at once, is of a different species altogether (Jenson 2000a:17).

This is what Jenson does in his narrative Trinitarian theology when he describe God as a history with us, as "event", as the triune God who creates by making room or by taking time in himself. Jenson offers this story of God to the postmodern world "openly and intentionally" as "the comprehensive truth" (Jenson 2000a:17) and not as a story among others. His defence against Nietzschean protest that such a metanarrative can (or must) be oppressive is that it cannot be because it is about the triune God. This might seem to be dissatisfactory to postmodernists, but the difference of Jenson's presentation of this story is in his notion that the church should embody this story and that this story still continues as part of God's story. Herein lies the more radical approach of Jenson than a mere modern one. His approach also differs from that of the "radical orthodoxy" that presents the Christian story not as "the" story, but as "a" story among others - a Christian counterstory. ${ }^{32}$ For Jenson "the" story is to be found in the church that must embody it in her liturgy, sacraments, and in her apocalyptic vision.

The value of Jenson's narrative approach is that he moves away from modernity's emphasis on abstract rationalism and this makes his theology much more postmodern. ${ }^{33}$ There is thus a broader understanding of the

32 Another approach is the option David Hart takes (also in following the radical orthodoxy) by presenting the Christian story not to persuade (with its violent implications), but to "attract" because of its "beauty".

33 Critique from Pannenberg (2000:53) on Jenson's methodology is for example that Jenson "too often seems to be taking up issues in an order that is determined more by rhetorical, even rhapsodic, impulse than by systematic necessity." However, Jenson makes an intentional decision about this methodology and therefore Mark Mattes (2000:485) says, for example, about Jenson's narrative approach: "Jenson is far more a 'post-modern' thinker than Pannenberg". 
truth in Jenson's work than in typical modern theology. ${ }^{34}$ Therefore, in his narrative theology Jenson presents a comprehensive story of the Trinitarian God and his creation. It is a narrative theology in essence and not just as an afterthought, and because Jenson incorporates all the aspects of his theology in his narrative structure the coherence of his theology is very strong. His presentation of God's story is one in which the story of God's identity as well as the story of the church and the world are all integrated as part of the history of whom God is. Jenson can therefore say without contradiction that the church is the story, the dramatic story of whom God is, and therefore she must live and celebrate it in order for the postmodern world to find in her a narratable world. The church's liturgy and Eucharist are excellent ways of celebrating this continuing story of God and His presence in the world, but the focus (or story) - and this is Jenson's significant emphasis - must then always be on the Trinitarian God. ${ }^{35}$

A further important value of Jenson's approach is that he describes the eschaton not as something separate or added to his theology, but as integral to the whole story. The eschaton is the logical end of the story which is necessary to give it its narrative structure. The "promise" of the church (or of the gospel or of God himself) is thus a logical and significant part of his theology. For Jenson it is crucial that the church will have a clear eschatological vision because that is their basis for living with hope. He states that the only alternative to faith in a God of hope is faith in sheer lack of hope that is in nihilism. Nihilism is seen by Jenson as the real threat of postmodernism and therefore the church's future as part of the triune converse - as theosis or as part of the fugue who God is - is for Jenson so important. He explains that modern Westerners have been taught by Scripture to construe history by its End, in accordance with a final sublimation into an infinite history. However: what happens if this promise is lost? What happens when those so taught no longer believe there is such an infinite history to be taken into? The answer according to Jenson is that they will then of course see precisely nothing for themselves (and their world) to be finally taken into and all those little sublations that make up their temporal existence will confront them with that void. Therefore "promise" is so important and Jenson writes indeed a theology of hope under the shadow of nihilism's threatening advent (Jenson 2000c:345) and

34 Jenson says of his narrative theology that it "does not suppose that truth taught by Aristotle or Newton is more foundational or comprehensive or natural than truth taught by Isaiah or John" (Jenson 2000c:339).

35 Pannenberg also emphasizes the importance of speaking about the Trinitarian God in Christian theology and not about a type of monotheism as the "God of the philosophers". He says "In Christian theology, there is no room for a pretrinitarian monotheism of the one God" (Pannenberg 2007:33). 
urges the church to live as the community of promise she already is. The church must not only remember and tell her story, but also see the end of her story and by doing that live with a promise (against the lack of promise of postmodernism) and with hope (against the hopelessness of nihilism). The church must have an apocalyptic vision; she must be able to see. ${ }^{36}$

\section{CONCLUSION}

Jenson identified story and promise as two challenges postmodernism raised for the Christian faith. These two issues are constantly addressed throughout his theology and in this article it became clear that Jenson's narrative Trinitarian theology gives a comprehensive and coherent answer to these challenges. That does not imply that Jenson's approach is unproblematic and some critique can indeed be raised against some of his theological views. ${ }^{37}$ This article can however conclude that Jenson's theology (in its essence and not only aspects of it) is indeed contributing to finding new perspectives to these postmodern challenges. For Jenson, the need and relevance of the particular Trinitarian story is crucial. It is always a specific story and a specific promise the church lives by and of which she must be a witness.

\section{BIBLIOGRAPHY}

BARTH, K.

1933. The Epistle to the Romans. Translated by Edwyn C. Hoskyns. Oxford: Oxford University Press.

Braten, C.E. \& Jenson, R.W. (eds.)

2002. The strange New Word of the Gospel. Re-Evangelizing in the Postmodern World. Grand Rapids: Eerdmans.

BUCKLEY, J.J.

2000. Intimacy: The Character of Robert Jenson's Theology. In: C.E. Gunton (ed.), Trinity, Time, and Church. A Response to the Theology of Robert W. Jenson (Grand Rapids: Eerdmans), pp. 10-22.

36 To see is again in contrast to modernity's methodological imperative to "abide by human reason alone" (Caputo \& Scanlon 1999:2).

37 Some of the critique against his theology is that it is a quasi-Hegelian system, that his argument against the timelessness of God is flawed, and that is promotes a "pan-en-trinitarianism". For more detail on these critiques, see my articles on Jenson, How is Robert Jenson telling the story? (2008) and Robert Jenson's ecumenical vision based on his Trinitarian thought (2011). 
CAPUto, J.D. \& SCANLon, M.J. (EDS.)

1999. God, the gift, and postmodernism. Bloomington: Indiana University Press.

FORD, D.F. (ED.)

1997. The Modern Theologians. An introduction to Christian Theology in the twentieth century. Oxford: Blackwell.

HART, D.B.

2003. The beauty of the infinite: The aesthetics of Christian truth. Grand Rapids: Eerdmans.

2005. The Lively God of Robert Jenson. First Things 156:28-34.

JeNSON, R.W.

1973. Story and Promise: A Brief Theology of the Gospel about Jesus. Philadelphia: Fortress Press.

1982. The Triune Identity: God according to the Gospel. Philadelphia: Fortress Press.

1993. How the world lost its story. First Things 36:19-24.

1997. Systematic Theology, Volume 1: The Triune God. Oxford: Oxford University Press.

1999a. Systematic Theology, Volume 2: The Works of God. Oxford: Oxford University Press.

1999b. The End is Music. In: S.H. Lee \& A.C. Guelzo (eds.), Edwards in our time: Jonathan Edwards and the shaping of the American religion (Grand Rapids: Eerdmans), pp. 161-171.

2000a. Can we have a story? First Things 101:16-17.

2000b. Introduction. In: C.E. Braaten \& R.W. Jenson (eds.), Sin, Death, \& the Devil (Grand Rapids: Eerdmans), pp. 1-6.

2000c. Second Thoughts about Theologies of Hope. Evangelical Quarterly 72(4):335-346.

2002a. The Great Transformation. In: C.E. Braaten \& R.W. Jenson (eds.), The last things: Biblical \& theological perspectives on eschatology (Grand Rapids: Eerdmans), pp.33-42.

2002b. What is a Post-Christian? In: C.E. Braaten \& R.W. Jenson (eds.), The strange New Word of the Gospel. Re-Evangelizing in the Postmodern World (Grand Rapids: Eerdmans), pp. 21-31.

2010. How the world lost its story. First Things 201:31-37.

KASPER, W.

2009. The timeliness of speaking of God: freedom and communion as basic concepts of theology. Worship 83(4):293-311. 
Mattes, M.C.

2000. An Analysis and Assessment of Robert Jenson's Systematic Theology. Lutheran Quarterly 14(4):463-494.

MiLbanK, J.

1990. Theology and social theory: beyond secular reason. Cambridge, Mass.: Blackwell.

Milbank, J, Pickstock, C. \& Ward, G (eds.) 1999. Radical Orthodoxy, A New Theology, London: Routledge

Nietzsche, F.

1954. From: On Truth and Lie in an Extra-moral Sense. In: W. Kaufmann (ed. \& transl.), The Portable Nietzsche (New York: Viking Press), pp. 46-47.

Pannenberg, W.

2000. A Trinitarian Synthesis. First Things 103:49-53.

2007. God of the Philosophers. First Things 174:31-34.

Peters, T.

1998. God Happens: The timeliness of the Triune God. The Christian Century 115(1):342-344.

Placher, W.C.

2004. The aesthetics of faith: God's beauty. The Christian Century 121(18):42-45.

STANLEY, T.

2008. Speaking credibly? Communicating Christian particularism in postmodern contexts. International Review of Mission 97(384-385):21-30.

VERHOEF, A.H.

2008. How is Robert Jenson telling the story? Scriptura: International Journal of Bible, Religion and Theology in Southern Africa 98(2):231-243.

2011. Robert Jenson's ecumenical vision based on his Trinitarian thought. Dutch Reformed Theological Journal 52(1-2):238-246.

WARD, G. (ED.)

1997. The Postmodern God: A Theological Reader. Oxford: Blackwell.

Keywords

Postmodernism

Eschatology

Narrative

Robert Jenson
Sleutelwoorde

Postmodernisme

Eskatologie

Narratiewe

Robert Jenson 